\title{
SLC34A2 wt Allele
}

National Cancer Institute

\section{Source}

National Cancer Institute. SLC34A2 wt Allele. NCI Thesaurus. Code C101435.

Human SLC34A2 wild-type allele is located in the vicinity of 4p15.2 and is approximately $23 \mathrm{~kb}$ in length. This allele, which encodes sodium-dependent phosphate transport protein 2B, is involved in sodium/phosphate co-transport. Mutation of the gene is associated with pulmonary alveolar microlithiasis. A chromosomal aberration involving this gene and the ROS1 gene may be associated with non-small cell lung cancer. 